\title{
The Effect of Temperature on Angiogenesis in Chicken Embryos
}

\author{
Emre ATAY ${ }^{*}$, Seval AYEKİN², Rabia Zülal HATİPOĞLU², Münevver Ceyda KURAL², Mert \\ KUSEYRİ², Yavuz TAÇYILDIZ², Yusuf BAŞOĞLU², Ali Batuhan ALKAN², Abdülkadir BİLİR', Tolga \\ ERTEKIN 1
}

\author{
${ }^{1}$ Afyonkarahisar Health Sciences University, Faculty of Medicine, Department of Anatomy, 03030, Afyonkarahisar, Turkey \\ ${ }^{2}$ Afyonkarahisar Health Sciences University, Faculty of Medicine, 03030, Afyonkarahisar, Turkey
}

\begin{abstract}
Angiogenesis plays an important role in the formation of new vessels in the embryonic period. The aim of this study is to determine possible differences in angiogenesis process in chicken embryos exposed to two different incubation temperatures of $37.5^{\circ} \mathrm{C}$ and $39.0^{\circ} \mathrm{C}$ using Chorioallantoic Membrane (CAM) model. The study included two groups, each with an experimental and control group, in which 16 fertilized chicken eggs were analyzed. The eggs were opened on the 7th day of incubation with the aid of forceps and surgical scissors without damaging the embryo. Head-stern, occipito-frontal length, vessel thickness, density and number of each embryo on CAM were measured by ImageJ. Statistical analysis of the data was performed by SPSS program. Depending on the temperature, there was a decrease, although not statistically significant, in the values of head-stern lengths of the embryos obtained from the eggs incubated at $39.0^{\circ} \mathrm{C}$. However, it was determined that occipito-frontal length values increased, the skull had a larger appearance and this increase was statistically significant $(\mathrm{p}<0.05)$. The mean density of embryos obtained from eggs incubated at $37.5^{\circ} \mathrm{C}$ was $1.58 \pm 0.57$, while the mean vessel density of embryos obtained from eggs incubated at $39.0^{\circ} \mathrm{C}$ was $1.46 \pm 0.61$. There was no statistically difference between mean vessel density values ( $\mathrm{p}>0.05)$. A comparison of both groups showed a decrease in the number of vascular branches $\left(35.44 \pm 10.97\right.$ at $37.5^{\circ} \mathrm{C}, 24.94 \pm 6.97$ at $\left.39.0^{\circ} \mathrm{C}\right)$ due to the increasing temperature. This decrease was found to be statistically significant $(\mathrm{p}<0.05)$. In general, it was observed that the increase in temperature caused a decrease in vessel density, thickness and number of branches in chicken embryos on CAM. As a result, it was determined that growth and development were negatively affected in embryos.
\end{abstract}

Keywords: Angiogenesis, chick, chorioallantoic membrane, temperature, vessel

\section{$* * *$ \\ Tavuk Embriyolarında Sıcaklığın Anjiyogenez Üzerine Etkisi}

ÖZ

Anjiyogenez embriyonik dönemde yeni damarların oluşumunda önemli bir rol oynar. Bu çalışmanın amacı, Koryoallantoik Membran (KAM) modeli kullanılarak $37.5^{\circ} \mathrm{C}$ ve $39.0^{\circ} \mathrm{C}$ olacak şekilde iki farklı kuluçka sıcaklığına maruz bırakılan tavuk embriyolarında anjiyogenez sürecindeki olası farklılıkları belirlemektir. Çalışmada her birinde 16'şar adet döllü tavuk yumurtasının analiz edildiği deney ve kontrol grubu olmak üzere iki grup yer aldı. Yumurtalar inkübasyonun 7 . gününde penset ve cerrahi makas yardımıyla embriyoya zarar vermeden açıldı. Fotoğrafları çekilen embriyoların tepe-kıç ve occipitofrontal uzunlukları ile KAM'daki damar kalınlıkları, damar yoğunluğu ve damar dal sayıları ImageJ programı kullanılarak ölçüldü. Verilerin istatistiksel analizi SPSS programı aracılığılla yapıldı. Sıcaklığa bağlı olarak $39.0^{\circ} C^{\prime}$ de inkübe edilen yumurtalardan elde edilen embriyoların tepe-kıç uzunluklarının değerlerinde istatistiksel olarak anlamlı olmasa da bir azalma mevcuttu. Bununla birlikte occipito-frontal uzunluk değerlerinin arttı̆̆1, kafatasının daha büyük bir görünüme sahip olduğu ve bu artışı istatistiksel olarak anlamlı olduğu tespit edildi $(\mathrm{p}<0.05) .37 .5^{\circ} \mathrm{C}$ 'de inkübe edilen yumurtalardan elde edilen embriyoların damar yoğunluğu ortalaması $1.58 \pm 0.57$ iken, $39.0^{\circ} \mathrm{C}$ 'de inkübe edilen yumurtalardan elde edilen embriyoların ortalama damar yoğunluğu 1.46 \pm 0.61 olarak tespit edildi. Ortalama damar yoğunluğu değerleri arasında istatistiksel olarak gruplar arasında bir fark gözlenmedi ( $>>0.05)$. Her iki grubun karşılaştırılmasında artan sıcaklığa bağlı olarak damar dal

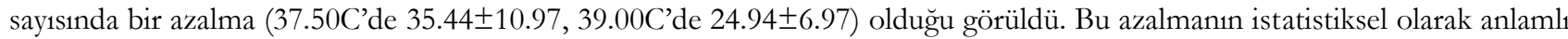
olduğu tespit edildi $(\mathrm{p}<0.05)$. Genel anlamda sıcaklık artışının tavuk embriyolarında KAM'da damar yoğunluğu, kalınlığ1 ve dal sayısında bir azalmaya sebep olduğu gözlendi. Sonuç olarak embriyolarda büyüme ve gelişmenin olumsuz yönde etkilendiği belirlendi.

Anahtar Kelimeler: Anjiyogenez, civciv, damar, koryoallantoik membran, sicaklık

To cite this article: Atay E. Ayekin S. Hatipoğlu R.Z. Kural M.C. Kuseyri M. Tacyuldı Y. Basoğlu Y. Alkan A.B. Bilir A. Ertekin T. The Effect of Temperature on Angiogenesis in Chicken Embryos. Kocatepe Vet J. (2020) 13(1):60-68

\footnotetext{
Submission: 10.12.2019 Accepted: 12.02.2020 Published Online: 18.02.2020

ORCID ID; EA: 0000-0002-2378-1183, SA: 0000-0001-9768-7336, RZH: 0000-0002-5640-566X,

MCK: 0000-0001-7675-4448, MK: 0000-0002-8999-6312, YT: 0000-0003-1020-0973, YB: 0000-0002-4380-4565,

ABA: 0000-0001-9130-3979, AB: 0000-0003-0633-9542, TE: 0000-0003-1756-4366

*Corresponding author e-mail: eemreatay@gmail.com
} 


\section{GİRİŞ}

Fizyolojik bir süreç olan anjiyogenez, mevcut kan damarlarından tomurcuklanma yolu ile yeni kan damarlarının oluşması ve gelişmesi şeklinde tanımlanmaktadır (Hagedorn ve Nerlich 2000, Kumar ve ark. 2005, Strohmeyer ve ark. 2000). Anjiyogenez hem embriyonik dönemde hem de yetişkinlik döneminde rol oynayan önemli bir süreçtir. Embriyonik dönemde anjiyogenez sürecinde damar yoğunluğunun artması ve yeni damarların oluşumu görülmektedir. Yetişkinlik döneminde ise anjiyogenez süreci bazı fizyolojik (menstürasyon, ovulasyon, gebelik, yara iyileşmesi ve epitelizasyonu gibi) ve patolojik olaylar neticesinde (diyabetik retinopati, tümör gelişimi, metabolik hastalıklar, inflamasyon ve dejenerasyon gibi) yeni damarların oluşumunda rol oynamaktadır (Bettencourt ve ark. 1998, Costa ve ark. 2004, Folkman 1986, Logan 1993, Nicholson ve Theodorescu 2004, Saraydaroğlu ve ark. 2004). İyileșmeyi etkileyen önemli faktörlerden biri yaralanan dokunun beslenmesi ve yeterli kan akımının sağlanmasıdır. Günümüzde anjiyogenez ile ilgili artan bilgi birikimi, birçok hastalı̆̆n oluşum mekanizmasının anlaşılmasına ve tedavi sürecinde yeni tedavi yaklașımlarının ortaya çıkmasına olanak sağlamaktadır (Townsend ve ark. 2004). Bu bağlamda anjiyogenez çalısmaları günümüzde aktif bir araştırma alanı olup, gelecek dönemlerde antianjiyojenik/proanjiyojenik tedavi yöntemlerine başvuracak insan sayısının 500 milyonun üzerinde olacağı düşünülmektedir (Norrby 2006).

Canlıların büyüme gelişme dönemi için sıcaklık önemli faktörlerden biridir. Son ylllarda gebeler üzerinde yapılan çalışmalarda ortam sıcaklığının erken doğum, düşük doğum ağırlığı ve ölü doğumlara neden olduğu bildirilmiştir. Bazı çalışmalarda ise yüksek ortam sıcaklığı ve aşırı sicaklık olaylarının preterm doğum ile ilişkili olduğu ve erken doğumu tetikleyebileceği ifade edilmiştir (Auger ve ark. 2014, Basu ve ark. 2010, Basu ve ark. 2017, Ha ve ark. 2017a, Ha ve ark. 2017b, Strand 2012, Zhang ve ark. 2017). Bu bilgiler 1şı̆̆ında çalışmamız sicaklığın anjiyogenez üzerindeki etkisinin ortaya konulmasina yönelik planlanmıştır.

Yapılan çalışmalarda tavuk embriyolarından elde edilen sonuçların memelilere de uyarlanabildiği görülmüş ve döllü tavuk ya da bıldırcın yumurtalarının model olarak kullanıldığı pek çok çalışma yapılmıştır (Ertekin ve ark. 2019, Guvenc ve ark. 2013, Guvenc ve ark. 2016, Mang1r ve ark. 2018, Ribatti 2016, Zhang ve ark. 2017). Bu tip çalışmaların insanlar ve memeli hayvanlar üzerinde yapilması her zaman mümkün olmadığından döllü kanatlı yumurtaları s1klıkla tercih edilmektedir. Bu tür modellerin tercih edilmesinin bir başka sebebi ise insan ve memeli hayvanların fizyolojik ve patolojik durumlardaki işlevlerinin bütünsellik göstermesi, çeşitli organ ve sistemlerin etkileșim halinde bulunmasıdır (Oral ve Çakar 2005).

Çalışmamızda embriyonik süreçteki anjiyogenezin farklı inkübasyon sıcaklığına göre değişimi Koryoallantoik Membran (KAM) modeli kullanılarak tespit edildi. KAM modeli kolay, basit ve tekrarlanabilir bir yöntem olmasıyla birçok çalışmada (kanser araştırmaları, damar gelişimi, embriyolojik malformasyonlar vs.) tercih edilmektedir (Dupertius ve ark. 2015, Leng ve ark. 2004, Özgürtaş 2009, Peng ve ark. 2009, Ribatti 2014). KAM modelinde anjiyogenez gelişimsel aşamalarına göre; erken faz (5.7. günler), ara faz (8.-12. günler) ve geç faz (13. günden itibaren) olmak üzere üç safhadan oluşmaktadır (Schlatter et al. 1997). Kapiller ağ erken fazda filizlenmeye başlamaktadır. Ara faz filizlenmenin sona erdiği ve mikrovasküler ağın gelişim gösterdiği aşamadır. Geç fazda ise, koryoallantoik ögeler embriyo etrafinda tam koruyucu bir membrana dönüşür ve genişlemesi tamamlanmaktadır (Hamburger ve Hamilton 1992). KAM modeli kullanılarak yapılan çalışmalarda anjiyogenez gelişim fazları göz önüne alınarak uygulamaların 5. günden itibaren yapılabileceği ifade edilmektedir (Hazel 2003). Bunun yan1 sira damarlanmanın olgunlaştı̆ı 12 . günden sonraki geç faz dönemin uygulamalar açısından daha iyi bir zamanlama olduğu da ifade edilmektedir (Leng ve ark. 2004). Bu bilgiler doğrultusunda çalışmamız, kapiller ağ ve damarlanmanın başladığı erken faz dönemi dikkate alınarak planlanmıştır. Çalışmamızın amacı, KAM modeli kullanılarak iki farklı kuluçka sıcaklığına maruz birakilan tavuk embriyolarında anjiyogenez sürecinde meydana gelen olas1 farkl11kklar1 belirlemektir.

\section{MATERYAL ve METOT}

Çalışma için Afyon Kocatepe Üniversitesi Hayvan Deneyleri Yerel Etik Kurulu (AKUHADYEK)'ndan 14/01/2019 tarihli ve 49533702/08 say1l etik kurul onayı alındı. Sicaklığın tavuk embriyoları üzerindeki etkisini incelemek üzere planlanan çalışmamızda 60 adet, 0 günlük, $65 \pm 5$ gr ağırllğında Specific Pathogen Free (SPF) döllü tavuk yumurtası kullanildı. SPF yumurtalar İzmir Bornova Veteriner Kontrol Enstitüsü'nden temin edildi.

Çalışma kapsamında deney ve kontrol olmak üzere iki grup oluşturuldu. Her grupta 30 adet döllü SPF yumurta kullanıldı. Kontrol grubundaki döllü SPF yumurtalar $37.5^{\circ} \mathrm{C}$ 'de $\% 60 \pm 5$ rölatif nemli ortamda horizontal pozisyonda 7 gün boyunca inkübe edildi. Deney grubundaki döllü SPF yumurtalar ise ilk 5 gün $37.5^{\circ} \mathrm{C}$ 'de $\% 60 \pm 5$ rölatif nemli ortamda horizontal pozisyonda, sonraki 2 gün ise $39.0^{\circ} \mathrm{C}$ de $\% 60 \pm 5$ rölatif nemli ortamda horizontal pozisyonda toplam 7 gün boyunca inkübe edildi. Her iki gruptaki 
yumurtalar eş zamanlı olarak ayrı makinalarda inkübe edildi (Resim 1).

7. günün sonunda her gruptaki yumurtaların döllü olup olmadığ1 1 ş1k kaynağ1 aracilığıyla belirlendi. Dölsüz ve bireysel hatalar neticesinde (embriyoya yumurtayı açarken zarar verme, yumurtanın kırılması vs.) kaybedilen yumurtalar çalışma dışında tutuldu. Her iki grupta ayrı ayrı toplam 16 adet döllü SPF yumurtada analiz yapild.

Yumurtalarda 1şık kaynağı altında embriyoların yeri belirlendi. Transversal olarak açlan yumurtalar petri kabına döküldü. $25 \mathrm{~cm}$ uzaklıktan tripod yardımıyla sabitlenen kamera aracılı̆̆ıla fotoğraflandı. Bu işlemden sonra embriyolar, damarlanindan penset ve makas yardımıyla ayrildı. Her embriyo ayr1 bir petri kabinda tepe-kıç ile occipito-frontal uzunluğu belirlemek üzere tekrar fotoğraflandı (Resim 2). Fotoğraflama işlemi bittikten sonra embriyoların ağırlıkları hassas terazi yardımıyla ölçüldü (Resim 3).

KAM'daki damar kalınlığı, damar yoğunluğu ve damar sayıs1 ImageJ (https://imagej.nih.gov/ij/) programı kullanılarak hesaplandı. Damar yoğunluğu ve damar dal sayisı KAM'da embriyoya en yakın ana damarlarından $0.5 \mathrm{~cm}$ uzaklıkta $1 \mathrm{~cm}^{2}$ lik rastgele seçilen 3 alanda belirlenirken, damar kalınlığ görüntü üzerindeki en kalın 3 damar belirlenerek ortalama kalınlık hesaplandı (Resim 4).

Verilerin istatistiksel analizi IBM SPSS Statistics 22.0 paket programı aracılığıyla yapıldı. Verilerin normal dağılıma uygunluğu Kolmogorov-Smirnov testi ile belirlendi. Veriler normal dağılım göstermediği için bağımsız grupların karşılaştırılmasında kullanılan ve nonparametrik bir test olan Mann Whitney U testi kullanıld1. $\mathrm{p}<0.05$ olan değerler istatistiksel olarak anlamlı kabul edildi. Tüm değerler ortalama \pm standart sapma (m士ss) şeklinde ifade edildi.

\section{BULGULAR}

Ölçülen parametrelerinin ortalama değerleri ve istatistiksel analizi Tablo 1'de gösterildi. $37.5^{\circ} \mathrm{C}$ 'de inkübe edilen yumurtalardan elde edilen embriyoların ortalama tepe-kıç uzunluğu 18.08 $\pm 1.72 \mathrm{~mm}$ iken, aynı parametrenin $39.0^{\circ} \mathrm{C}$ 'de inkübe edilen yumurtalardan

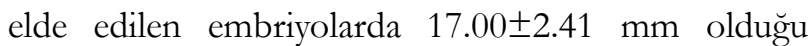
belirlendi. Sicaklığın arttırılmasına bağlı olarak ortalama tepe-kıç uzunluğunun azaldığının görülmesine rağmen, gruplar arasında istatistiksel olarak anlamlı bir fark belirlenmedi ( $p>0.05)$. Occipito-frontal uzunluğa ait ortalama değerlere bakıldığında; $37.5^{\circ} \mathrm{C}$ 'de inkübe edilen yumurtalardan elde edilen embriyoların ortalama değerinin (6.73 $1.08 \mathrm{~mm}), \quad 39.0^{\circ} \mathrm{C}^{\prime} \mathrm{de}$ inkübe edilen yumurtalardan elde edilen embriyoların ortalama değerinden $(8.06 \pm 1.11 \mathrm{~mm})$ daha düşük olduğu görüldü. $\mathrm{Bu}$ farkın ise istatistiksel olarak anlamlı olduğu tespit edildi $(\mathrm{p}<0.05)$. Tepe-kıç ve occipitofrontal uzunluğa ait yapılan ölçümlerin genel değerlendirilmesinde, sicaklığa bağlı olarak $39.0^{\circ} \mathrm{C}$ 'de inkübe edilen yumurtalardan elde edilen embriyolarının boy uzunluğunda bir azalma mevcutken, occipito-frontal mesafenin arttığ1 ve kafatasının daha büyük bir görünüme sahip olduğu tespit edildi.

Her iki sıcaklığa maruz kalan embriyoların ağırlıkları ölçülmüss ve $39.0^{\circ} \mathrm{C}$ 'de inkübe edilen yumurtalardan elde edilen embriyoların ağırlığının $(0.42 \pm 0.11 \mathrm{gr})$ $37.5^{\circ} \mathrm{C}$ 'de inkübe edilen yumurtalardan elde edilen embriyolardan $(0.54 \pm 0.12 \mathrm{gr})$ daha az olduğu belirlenmiştir. Aynı zamanda ağırlık açısından gruplar arasında istatistiksel olarak anlamlı bir fark olduğu görüldü $(\mathrm{p}<0.05)$.

$37.5^{\circ} \mathrm{C}$ 'de inkübe edilen yumurtalardan elde edilen embriyolara ait KAM'daki damar yoğunluğu ortalamas1 $\% 1.58 \pm 0.57, \quad 39.0^{\circ} \mathrm{C}$ 'de inkübe edilen yumurtalardan elde edilen embriyolarin damar yoğunluğu ortalaması ise $\% 1.46 \pm 0.61$ olarak hesaplanirken gruplar arasinda istatistiksel olarak bir fark gözlenmedi ( $>00.05)$. Damar kalınlığ1 ele alındığında yüksek sıcaklıkta inkübe edilen yumurtalardan elde edilen embriyolarin ortalama değerinin kontrol grubuna göre daha düşük olduğu görüldü. Damar kalınlıkları arasındaki bu farkın istatistiksel olarak anlamlı olduğu tespit edildi ( $p<0.05$, Tablo 1). Damar dal sayisinda kontrol grubuna göre bir azalma olduğu görüldü. Bu azalmanın istatistiksel olarak anlamlı olduğu tespit edildi ( $\mathrm{p}<0.05$, Tablo 1). 


\section{KONTROL GRUBU}

\section{DENEY GRUBU}
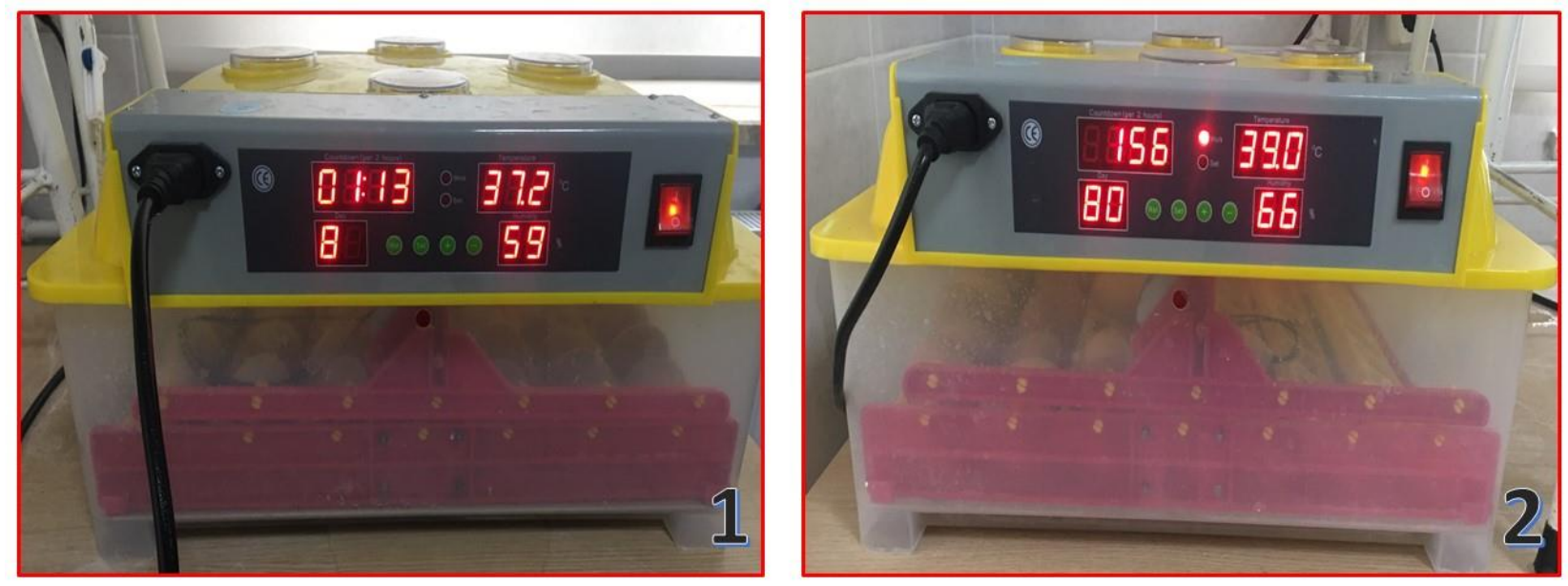

Resim 1. Fertilize Specific Pathogen Free (SPF) yumurtaların inkübasyon cihazına yerleştirilmesi. (1) Kontrol Grubu, (2) Deney Grubu

Figure 1. Fertilized Specific Pathogen Free (SPF) eggs in the incubator. (1) Control Group, (2) Experimental Group

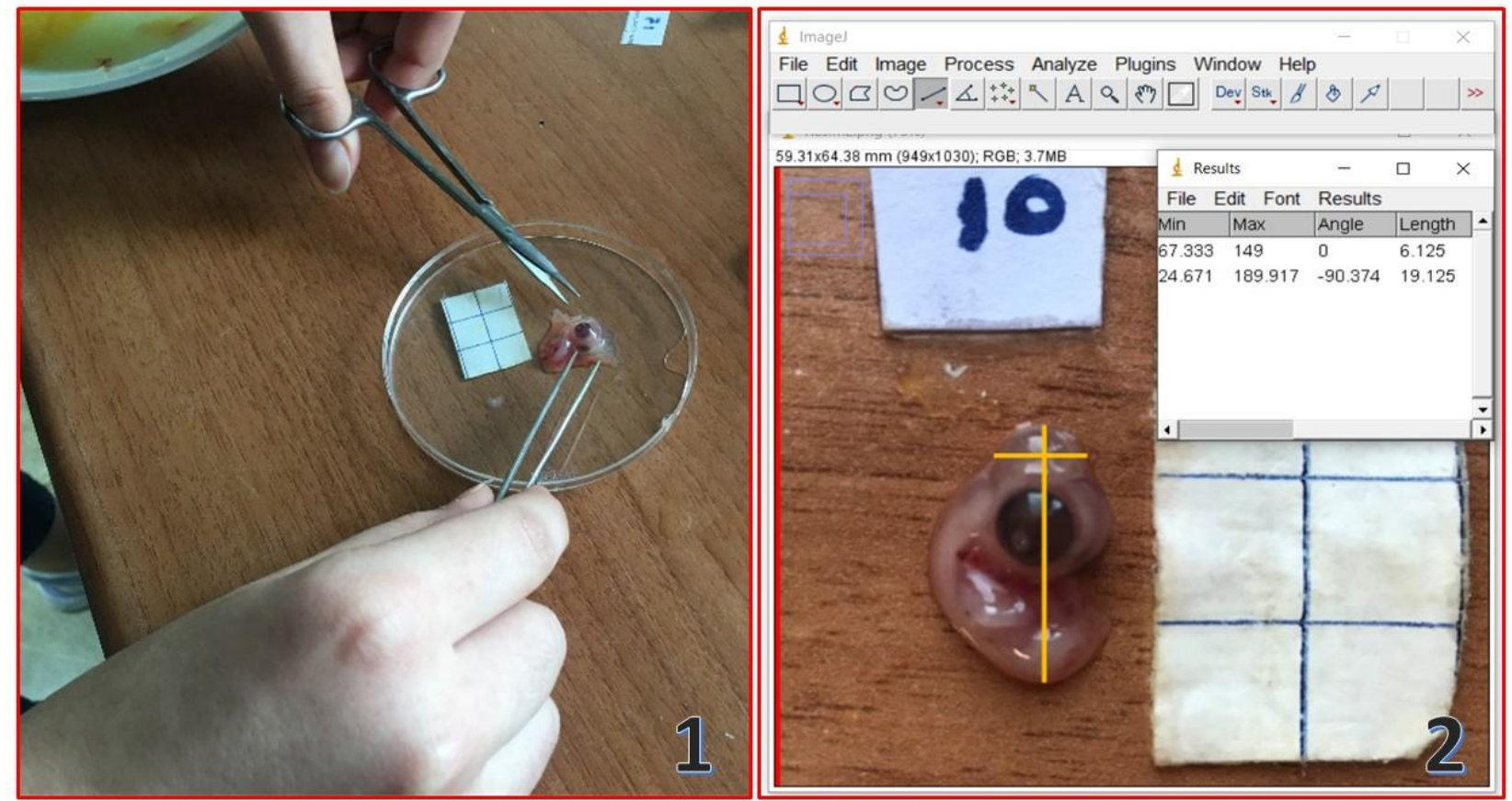

Resim 2. Embriyoların petri kabına alınması. (1) Embriyoların damarlarından ayrilmas1, (2) ImageJ programı ile tepe-kıç ve occipito-frontal uzunluk ölçümü

Figure 2. Embryos are taken into the petri dish. (1) Separation of embryos from vessels, (2) Head-stern and occipito-frontal length measurement with ImageJ program 


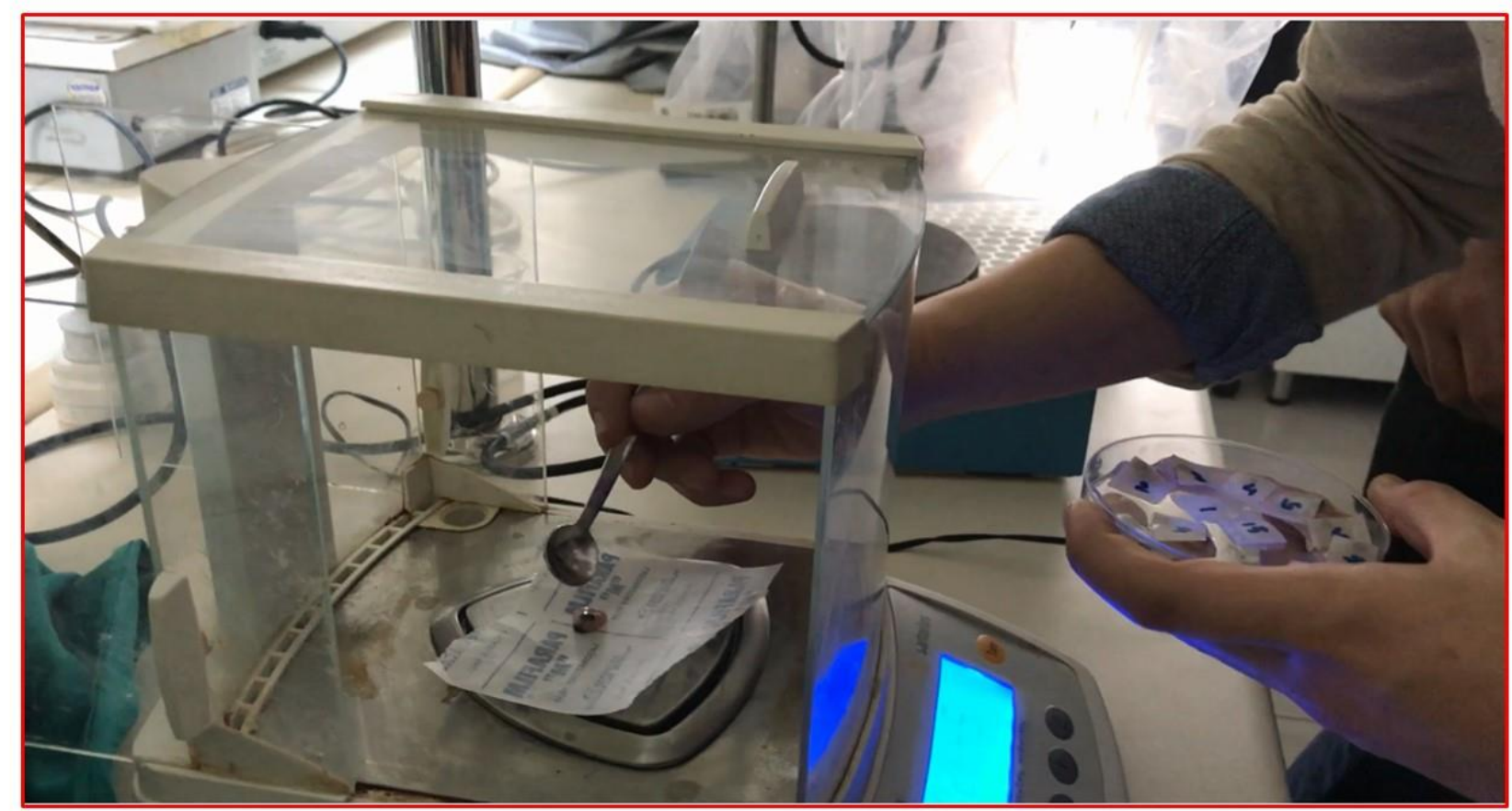

Resim 3. Embriyoların ağırlık ölçümü

Figure 3. Weight measurement of embryos

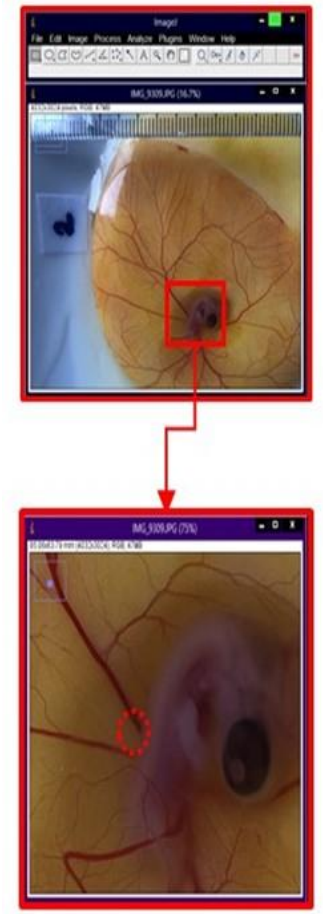

Embriyoların damar kalınlığının ölçümü
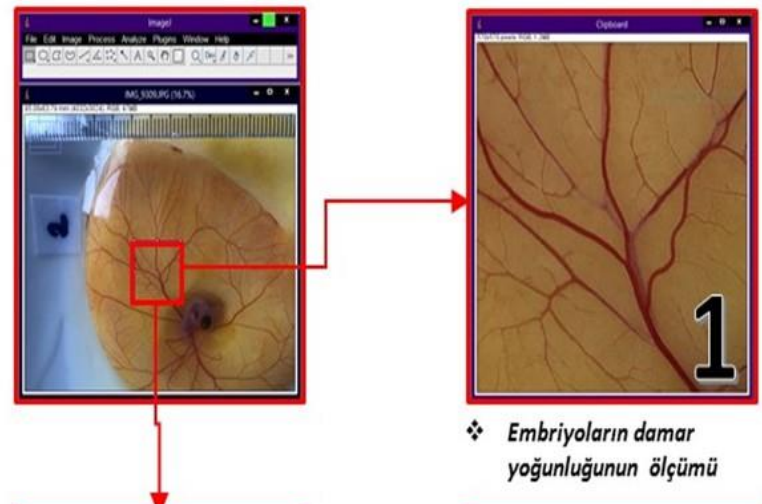

* Embriyoların damar yoğunluğunun ölçümü
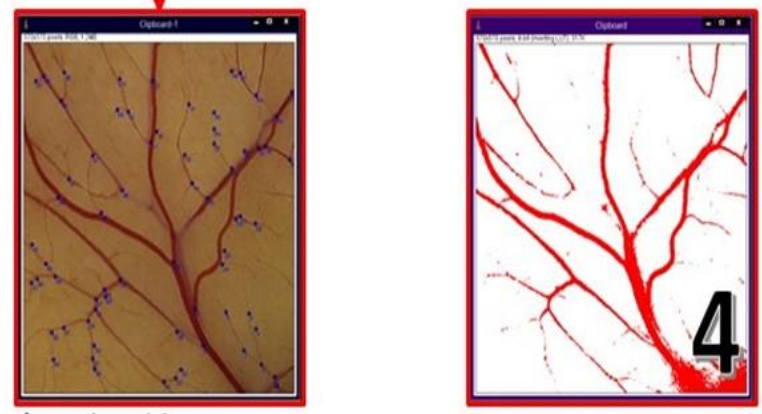

Embriyodaki

dallanmaların ölçümü
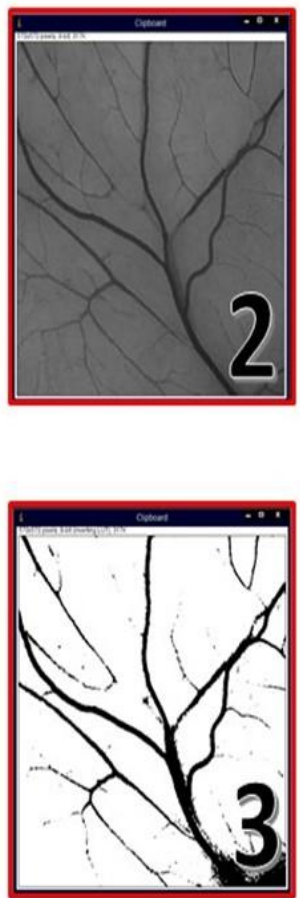

Resim 4. ImageJ programı ile yapılan analiz basamakları. (1) Damar görüntüsünün büyütülmesi, (2) Görüntünün arka planının temizlenmesi, (3) Damarların belirginleştirilmesi, (4) Renkli görüntüde damar yoğunluğunun hesaplanmasi

Figure 4. Analysis steps performed with Image J program. (1) Enlarging the vessel image, (2) Clearing the background of the image, (3) Clarification of the vessels, (4) Calculating the vessel density in color image 
Tablo 1. Ölçüm parametrelerine ait ortalama değerler

Table 1. Mean values of the measurement parameters

\begin{tabular}{|c|c|c|c|c|c|c|c|}
\hline & \multicolumn{4}{|c|}{$37.5^{\circ} \mathrm{C}$} & \multicolumn{2}{|c|}{$39.0^{\circ} \mathrm{C}$} & $\mathrm{p}$ \\
\hline Ölçüm Parametreleri & $\mathbf{n}$ & Min-Max & $\mathrm{m} \pm \mathrm{ss}$ & $\mathrm{n}$ & Min-Max & $\mathrm{m} \pm \mathrm{ss}$ & \\
\hline Baş Kıç Uzunluğu (mm) & 16 & $14.30-20.62$ & $18.08 \pm 1.72$ & 16 & $12.33-21.21$ & $17.00 \pm 2.41$ & 0.132 \\
\hline $\begin{array}{l}\text { Occipito-Frontal Uzunluk } \\
\text { (mm) }\end{array}$ & 16 & $4.96-8.78$ & $6.73 \pm 1.08$ & 16 & 6 & 1 & $1 *$ \\
\hline Ağırlık (gr) & 16 & $0.32-0.77$ & $0.54 \pm 0.12$ & 16 & $0.18-0.55$ & $0.42 \pm 0.11$ & $0.020 *$ \\
\hline $\begin{array}{c}\text { Damar Yoğunluğu Ortalamas1 } \\
(\%)\end{array}$ & 16 & $0.78-2.71$ & 7 & 16 & $0.47-2.94$ & 0.0 & .598 \\
\hline $\begin{array}{c}\text { Damar Kalınlığı Ortalaması } \\
\qquad(\mathrm{mm})\end{array}$ & 16 & $0.28-0.83$ & $0.48 \pm 0.16$ & 16 & $0.25-0.61$ & $0.37 \pm 0.10$ & $0.033 *$ \\
\hline Dal Sayısı Ortalaması (adet) & 16 & $18.00-56.00$ & $35.44 \pm 10.97$ & 16 & $10.00-38.00$ & $24.94 \pm 6.97$ & $0.005^{*}$ \\
\hline
\end{tabular}

* Mann Whitney U testi, $\mathrm{p}<0.05$ istatistiksel olarak anlamlı

\section{TARTIŞMA ve SONUÇ}

Embriyonik gereksinimlerin karşılanması ve maksimum kuluçka randımanı elde edilmesi için kuluçka koşullarının çok iyi ayarlanması gerekir (Meijerhof 2009). Bu bağlamda sicaklık, inkübasyon sırasında dikkat edilmesi gereken en önemli faktörlerden biridir. Sicaklık civciv kalitesini ve kuluçka sonrası performansını etkilemekle birlikte embriyonik büyüme ve gelişmeye de katk1 sağlamaktadır (Christensen ve ark. 1999, French 1994, Ricklefs 1987, Lourens ve ark. 2005). İnkübasyon sırasında doğru embriyo sıcaklı̆̆ının ve inkübatör sıcaklık ayarının korunmasının önemli olduğu kanıtlanmıştır (Lourens ve ark. 2005, Meijerhof 2009). Yapılan çalışmalar, inkübasyonun 19. gününe kadar $37.8^{\circ} \mathrm{C}$ 'lik sabit yumurta kabuğu sıcaklığının en yüksek kuluçka randımanı ve en düşük embriyo mortalitesi ile sonuçlandığını göstermiştir (Lourens ve ark. 2005, Lourens ve ark. 2007). Leksrisompong ve ark. (2007) $39.5^{\circ} \mathrm{C}$ ve daha yüksek bir yumurta kabuğu sicaklığının embriyonun kalp, karaciğer, taşlik, proventrikulus (ön mide) ve bağırsaklarının büyümesini geciktirdiğini bildirmişlerdir. Yapılan çalışmalar kuluçka sıcaklık değişimlerinin tavuk embriyo gelişimini olumsuz etkilediğini bildirmektedir (Leksrisompong ve ark 2007, Maatjens ve ark. 2014, Maatjens ve ark. 2016a). Çalışmamızda kuluçka sicaklığının $\quad 37.5^{\circ} \mathrm{C}$ 'den $\quad 39.0^{\circ} \mathrm{C}$ 'ye arttırlmasinın KAM'daki damar yoğunluğu, damar kalınlığı ve dal sayısında belirgin bir azalmaya neden olduğu tespit edildi. Aynı zamanda damar gelişiminin geri kalması ve buna bağlı olarak yeterli kan dolaşımının sağlanamamasının embriyo gelişimini olumsuz etkilediği kanaatindeyiz.

Maatjens ve ark. (2016a)'nın sicaklığın tavuk embriyolar1 üzerindeki etkilerine yönelik yaptıklar1 çalıșmalarında, farklı sıcaklıklara maruz kalan döllü yumurtalardan elde edilen civcivlerin vücut ağırlığının yüksek inkübasyon sıcaklığından düşük inkübasyon sıcaklığına doğru kademeli bir azalma gösterdiğini ifade etmişlerdir. Hulet ve ark. (2007)'nın yaptıkları bir başka çalışmada ise $37.5^{\circ} \mathrm{C}$ 'lik inkübasyon sıcakllğındaki civciv ağıllı̆̆ının $38.6^{\circ} \mathrm{C}$ ve $39.7^{\circ} \mathrm{C}$ 'ye göre daha düşük olduğu bulunmuştur. Ancak bu sonuçların aksine birçok çalışmada yüksek inkübasyon sicaklığına maruz kalan döllü yumurtalardan elde edilen civcivlerin ağırlı̆̆ının daha düşük olduğu belirlenmiştir (Leksrisompong ve ark. 2007, Lourens ve ark. 2005, Molenaar ve ark. 2011). Çalışmamızda da bu sonuçlara benzer şekilde inkübasyon sıcaklığının artmasına bağlı olarak tavuk embriyo ağırlı̆ıııın azaldığı ve bu farkın istatistiksel olarak anlamlı olduğu tespit edildi (Tablo 1).

Maatjens ve ark. (2016b)'nı çalışmasında inkübasyonun son haftasındaki (inkübasyonun 15.-19. günleri arasında) sıcaklık değişikliklerinin tavuk embriyosu gelişimi üzerine etkileri incelenmiştir. Civciv kalitesi ve organ gelişimine ait parametreler inkübasyondan sonraki 7. günde değerlendirilmiştir. İnkübasyon sicaklığının $35.6^{\circ} \mathrm{C}$ ve $36.7^{\circ} \mathrm{C}$ olduğu gruplardan elde edilen civcivlerin ortalama boylarının (sirasiyla $20.5 \mathrm{~cm}, 20.6 \mathrm{~cm}$ ) benzer olduğu, sicaklığın $37.8^{\circ} \mathrm{C}$ ve $38.9^{\circ} \mathrm{C}$ ye arttırıldığ gruplarda ise ortalama civciv boyunda azalmanın (sirasiyla $20.3 \mathrm{~cm}, 20.1 \mathrm{~cm}$ ) olduğu ifade edilmiştir. Sunulan bu çalışmada ise embriyoların ortalama tepe-kıç uzunluk değeri $37.5^{\circ} \mathrm{C}$ 'de daha yüksek bulunurken $(18.08 \pm 1.72 \mathrm{~mm})$; sıcaklık $39.0^{\circ} \mathrm{C}$ ye yükseltildiğinde bu değerin azaldığ $(17.00 \pm 2.41 \mathrm{~mm})$ görülmüştür.

Maatjens ve ark. (2014)'nın organ gelişimini değerlendirmeye yönelik çalışmasında tavuk embriyoları inkübasyonun 19. gününden son gününe kadar $36.7,37.8$ ve $38.9^{\circ} \mathrm{C}$ 'lik üç farklı sıcaklığa maruz bırakılmışır. Çalışma neticesinde $38.9^{\circ} \mathrm{C}^{\prime}$ lik inkübasyon sicakllğında diğer inkübasyon sıcaklıklarına göre kalp, mide ve karaciğer ağırllğının daha düşük olduğunu bildirmişlerdir.

Yumurta inkübasyon sicaklığ1 ve metabolik hiz arasındaki pozitif ilişkinin kurulması çok önemlidir. Çünkü metabolik hız, embriyonun oksijen talebini yönlendirmektedir (Lourens ve ark. 2007, Romijn ve ark. 1956). Yapılan çalışmalar, inkübasyonun 15. gününden itibaren inkübasyon sicaklığın $37.8^{\circ} \mathrm{C}$ 'den 
$38.9^{\circ} \mathrm{C}$ ye arttırlmasının normal olarak metabolik hızda ani bir artışla sonuçlandı̆̆ını, bununda da embriyonik 1s1 üretimini dolayısiyla embriyonik büyüme ve gelişmeyi negatif yönde etkilediğini göstermiştir (Christensen ve ark. 1999, Lourens ve ark. 2006, Ricklefs 1987, Romanoff 1936). Bununla birlikte inkübasyon sıcaklığındaki azalma, koryoallantoik membranda kan akımının azalmasına neden olmaktadır. Bu da embriyo gelişimi esnasında olumsuz reaksiyonların gerçekleșmesini sağlamaktadır (Tzschentke, 2007). Oksijen ihtiyacının karşılanması ve kan akımının düzenli bir şekilde gerçekleşmesi iyi bir damar ağı gelişimi ile sağlanmaktadır. Kan damarlarının gelişimi sırasında vaskülogenez ve anjiyogenez mekanizmaları görev yapmaktadır (Risau, 1997).

Tavuk embriyolarında KAM modeli kullanılarak vaskülogenez ve anjiyogenez süreçleri incelenmektedir. KAM modelinde koryonik epitelyumun aktif göçü açıç̧a görülmektedir, vaskülogenez ve anjiyogenez süreçleri büyük ölçüde koryonik epitelyumun büyümesinden ve farklılaşmasından kaynaklanmaktadır (Ribatti, 2008). Birçok çalışmada inkübasyonun erken aşamalarında oluşan ve üstteki koryonik epitelyal hücrelerle yakından ilişkili bir kılcal pleksus oluşumu tanımlanmıştır (Ausprunk ve ark. 1974, Burton ve ark. 1989, Danchakoff 1917, Fanczi ve ark. 1979, Moscona 1959 Ribatti ve ark. 1998). Danchakoff (1917), mezenkimal kan damarlarından kaynaklanan ve koryonik epitelyumu istila eden, iyi perfüze edilmiş bir kılcal ăg ile sonuçlanan çok sayıda filiz tarif etmiştir. Burton ve ark. (1989) ise kısa vasküler tomurcukların arteriyel ve venöz taraftan mezenşimi işgal ettiğini ve inkübasyonun 6. gününde kılcal pleksus oluşumuyla sonuçlandığını bildirmiştir. De Fouw ve ark. (1989)'nın kapsamlı bir morfometrik araştırmasında, KAM yüzeyinin inkübasyon sürecinde 6. günde $6 \mathrm{~cm}^{2} \mathrm{den}$, 14. günde $65 \mathrm{~cm}^{21}$ ye hızlı bir şekilde genişlediğini göstermiştir. Bu süre zarfında, KAM yüzeyindeki besleyici damarların sayısının (prekapiller ve kapiller damarların sayısı 2.5 ve 5 kat oranında artmıștır) ağırlıklı olarak inkübasyonun 10. gününden sonra büyüme ve yeniden modelleme nedeniyle arttığını ifade etmişlerdir. Literatür bilgilerine göre inkübasyonun erken aşamalarında vaskülogenez ve anjiyogenez süreçlerinin başladığ görülmektedir. Aynı zamanda damar sayss ve yoğunluğu artmakta böylelikle normal büyüme ve gelişme süreçleri devam etmektedir. Çalışmamızda ise $39.0^{\circ} \mathrm{C}$ sicaklığa maruz kalan döllü tavuk yumurtalarının, normal inkübasyon koşullarındaki $\left(37.5^{\circ} \mathrm{C}\right.$ ve $\% 60 \pm 5$ rölatif nemli ortam) döllü tavuk yumurtalarına göre KAM yüzeyinde damar yoğunluğu, damar kalınlığ1 ve dal sayısında bir azalma olduğu belirlendi (Tablo 1). Buna bağlı olarak yeterli dolaşımın sağlanamamasıyla embriyolarda büyüme ve gelişmenin olumsuz yönde etkilendiği gözlendi.
Sonuç olarak; yeni bir bakış açısı oluşturmaya yönelik uyguladığımız KAM modelinin ileride yapılması planlanan çalışmalarda kullanılabilir olduğu ve literatüre katkı sağlayacağı kanaatindeyiz.

\section{TEŞEKKÜR}

> Afjon Kocatepe Üniversitesi Hayvan Deneyleri Yerel Etik Kurulu (AKUHADYEK)'ndan 14/01/2019 taribli ve 49533702/08 saynl etik kurul onayn alndi.

Çıkar Çatışması: Yazarlar, çıkar çatışması olmadığını beyan eder.

\section{KAYNAKLAR}

Auger N, Naimi AI, Smargiassi A, Lo E, Kosatsky T. Extreme heat and risk of early delivery among preterm and term pregnancies. Epidemiology. 2014; 25:344-350.

Ausprunk DH, Knighton DR, Folkman J. Differentiation of the vascular endothelium in the chick chorioallantois: A structural and autoradiographic study. Dev Biol. 1974; $38: 237-247$.

Basu R, Chen H, Li DK, et al. The impact of maternal factors on the association between temperature and preterm delivery. Environ Res. 2017; 154:109-114.

Basu R, Malig B, Ostro B. High ambient temperature and the risk of preterm delivery. Am J Epidemiol. 2010; 172:1108-1117.

Bettencourt MC, Bauer JJ, Sesterhenn IA, Connelly RR, Moul JW. CD34 immunohistochemical assesment of angiogenesis as a prognostic marker for prostate cancer recurrence after radical prostatectomy. The Journal of Urology. 1998; 160:459-65.

Burton GJ, Palmer ME. The chorioallantoic capillary plexus of the chicken egg: A microvascular corrosion casting study. Scanning Microsc. 1989; 3:549-558.

Christensen VL, Donaldson WE, Nestor KE. Length of the plateau and pipping stages of incubation affects the physiology and survival of turkeys. Br Poult Sci. 1999; 40:297-303.

Costa C, Soares R, Schmitt F. Angiogenesis: now and then. APMIS. 2004; 112:402-412.

Danchakoff $\mathbf{V}$. The position of the respiratory vascular net in the allantois of the chick. Am J Anat. 1917; 21:407-419.

Dupertuis YV, Delie F, Cohen M, Pichard C. In ovo method for evaluating the effect of nutritional therapies on tumor development, growth and vascularization. Clinical Nutrition Experimental. 2015; 2:9-17.

Ertekin T, Bilir A, Aslan E, Koca B, Turamanlar O, Ertekin A, Albay S. The effect of diclofenac sodium on neural tube development in the early stage of chick embryos. Folia Morphol (Warsz). 2019; 78(2):307-313.

Fanczi T, Feher S. Ultrastructural studies of chicken embryo CAM during incubation. Anat Histol Embryol. 1979; 8:151-159.

Folkman J. How is blood vessel growth regulated in normal and neoplastic tissue?G.H.A. Clowes memorial award lecture. Cancer Res. 1986; 46(2):467-73.

French NA. Effect of incubation temperature on the gross pathology of turkey embryos. Br Poult Sci. 1994; 35:363371. 
Guvenc Y, Billur D, Aydin S, Ozeren E, Demirci A, Alagoz F, Dalgic A, Belen D. Metamizole Sodium Induces Neural Tube Defects in a Chick Embryo Model. Turk Neurosurg. 2016; 26(3):445-8.

Guvenc Y, Dalgic A, Billur D, Karaoglu D, Aydin S, Daglioglu E, Ozdol C, Nacar OA, Yildirim AE, Belen D. The effects of levetiracetam on neural tube development in the early stage of chick embryos. Turk Neurosurg. 2013; 23(5):617-22.

Ha S, Liu D, Zhu Y, Kim SS, Sherman S, Mendola P. Ambient temperature and early delivery of singleton pregnancies. Environ Health Perspect. 2017a; 125:453459.

Ha S, Zhu Y, Liu D, Sherman S, Mendola P. Ambient temperature and air quality in relation to small for gestational age and term low birthweight. Environ Res. 2017b; 55:394-400.

Hagedorn HG, Nerlich AG. Microvessel density and endothelial basement membrane composition in laryngeal squamous cell carcinomas. Acta Otolaryngol. 2000; 120:891-98.

Hamburger V, Hamilton HL. A series of normal stages in the development of the chick embryo. 1951. Dev Dyn. 1992; 195(4):231-72.

Hazel SJ. A novel early chorioallantoic membrane assay demonstrates quantitative and qualitative changes caused by antiangiogenic substances. J Lab Clin Med. 2003; 141:217-228.

Hulet R, Gladys G, Hill D, Meijerhof R, El-Shiekh T. Influence of egg shell embryonic incubation temperature and broiler breeder flock age on posthatch growth performance and carcass characteristics. Poult Sci. 2007; 86(2):408-412.

Kumar V, Abbas AK, Fausto N. Tissue renewal and repair: regeneration, healing, and fibrosis. In: Robbins and Cotran Pathologic Basis of Disease. 7th edition, Philedelphia, Pennsylvania. Elsevier Saunders Company. 2005; 87-119.

Leng T, Miller JM, Bilbao KV, et al. The chick chorioallantoic membrane as a model tissue for surgical retinal research and simulation. Retina. 2004 Jun; 24(3):427-434.

Leksrisompong N, Romero-Sanchez H, Plumstead PW, Brannan KE, Brake J. Broiler incubation. 1. Effect of elevated temperature during late incubation on body weight and organs of chicks. Poult Sci. 2007; 86(12):26852691.

Logan A. Angiogenesis. Lancet. 1993; 341:1467-1468.

Lourens A, van den Brand H, Meijerhof R, Kemp B. Effect of eggshell temperature during incubation on embryo development, hatchability, and posthatch development. Poult Sci. 2005; 84(6):914-920.

Lourens A, van den Brand H, Heetkamp MJW, et al. Effect of egg size on heat production and the transition of energy from egg to hatchling. Poult Sci. 2006; 85:770776.

Lourens A, van den Brand H, Heetkamp MJ, Meijerhof R, Kemp B. Effects of eggshell temperature and oxygen concentration on embryo growth and metabolism during incubation. Poult Sci. 2007; 86(10):2194-2199.

Maatjens CM, van Reijink IA, Molenaar R, van der Pol CW, Kemp B, van den Brand $\mathbf{H}$. Temperature and $\mathrm{CO}_{2}$ during the hatching phase. I. Effects on chick quality and organ development. Poult Sci. 2014; 93(3):645-654.
Maatjens CM, van Roovert-Reijrink IA, Engel B, van der Pol CW, Kemp B, van den Brand $\mathbf{H}$. Temperature during the last week of incubation. I. Effects on hatching pattern and broiler chicken embryonic organ development. Poult Sci. 2016a; 95(4):956-965.

Maatjens CM, van Roovert-Reijink IA, van den Anker I, Engel B, van der Pol CW, Kemp B, van den Brand H. Temperature during the last week of incubation. II. Effects on first week broiler development and performance. Poult Sci. 2016b; 95(9):2136-2144.

Mangir N, Raza A, Haycock JW, Chapple C, Macneil S. An improved in vivo methodology to visualise tumour induced changes in vasculature using the chick chorionic allantoic membrane assay. In Vivo. 2018; 32(3):461-472.

Meijerhof R. The influence of incubation on chick quality and broiler performance. Proceedings of the 20th Australian Poultry Science Symposium, 2009, Sydney, New South Wales, Australia, 9-11th February 2009. 2009; pp.167-170.

Molenaar R, Hulet R, Meijerhof R, Maatjens CM, Kemp B, van den Brand $\mathbf{H}$. High eggshell temperatures during incubation decrease growth performance and increase the incidence of ascites in broiler chickens. Poult Sci. 2011; 90(3):624-632.

Moscona A. Squamous metaplasia and keratinization of chorionic epithelium of the chick embryo in egg and culture. Dev Biol. 1959; 1:1-23.

Nicholson B, Theodorescu D. Angiogenesis and prostate cancer tumor growth. J Cell Biochem. 2004; 91(1):125150.

Norrby K. In-vivo models of angiogenesis. J Cell Mol Med. 2006; 10:588-612.

Oral M, Çakar S. Deneysel hayvan çalışmalarında etik prensipler. Anestezi Dergisi 2005; 13(2):75-82.

Özgürtaş Y. Anjiyogenezde bir in-vivo model: civciv koriyoallantoik membran. Gülhane Tip Dergisi 2009; 51:67-69.

Peng CC, Hsieh CL, Lin LY, Chyau CC, Cheng YT, Chen KC, Peng RY. Anisotropic diffusion deviates chicken embryo chorioallantoic membrane assay (CAM) to reflect inherent therapeutic behaviors. Colloids Surf B Biointerfaces. 2009; 70(1):29-34.

Ribatti D, Bertossi M, Nico B, Vacca A, Ria R, Riva A, Roncali L, Presta M. Role of basic fibroblast growth factor in the formation of the capillary plexus in the chick embryo chorioallantoic membrane. An in situ hybridization, immunohistochemical and ultrastructural study. J Submicrosc Cytol Pathol. 1998; 30:127-136.

Ribatti D. Chick embryo chorioallantoic membrane as a useful tool to study angiogenesis. Int Rev Cell Mol Biol. 2008; 270:181-224.

Ribatti D. The chick embryo chorioallantoic membrane as a model for tumor biology. Exp Cell Res. 2014 Nov 1;328(2):314-24.

Ribatti D. The chick embryo chorioallantoic membrane (CAM). A multifaceted experimental model. Mech Dev. 2016; 141:70-77.

Ricklefs RE. Comparative analysis of avian embryonic growth. J Exp Biol. 1987; 1:309-323.

Risau W. Mechanisms of angiogenesis. Nature. 1997; 386:671674.

Romanoff AL. Effects of different temperatures in the incubator on the prenatal and postnatal development of the chick. Poult Sci. 1936; 15:311-315. 
Romijn C, Lokhorst W. The caloric equilibrium of the chicken embryo. J Physiol. 1956; 150:239-249.

Saraydaroğlu Ö, Özuysal S, Bilgin T. İnvaziv serviks karsinomlarında anjiogenezin prognostik faktörler üzerine etkisi. Türk Patoloji Dergisi. 2004; 20(1-2):14-17.

Schlatter P, Konig MF, Karlsson LM, Burri PH. Quantitative study of intussusceptive capillary growth in the chorioallantoic membrane (CAM) of the chicken embryo. Microvasc Res. 1997; 54:65-73.

Strand LB, Barnett AG, Tong S. Maternal exposure to ambient temperature and the risks of preterm birth and stillbirth in Brisbane, Australia. Am J Epidemiol. 2012; 175(2):99107.

Strohmeyer D, Rössing C, Bauerfeind A, Kaufmann O, Schlechte H, Bartsch G, Loening S. Vasculer endothelial growth factor and its correlation with angiogenesis and p53 expression in prostate cancer. Prostate. 2000; 45:216-224.

Townsend CM, Beauchamp DR, Evers MB, Mattox KL. Sabiston textbook of surgery: the biological basis of modern surgical practice. 17th ed. Elsevier Saunders, Philadelphia, 2004.

Tzschentke B. Attainment of thermoregulation as affected by environmental factors. Poult. Sci. 2007; 86:1025-1036.

Zhang JJ, Jo JO, Huynh DL, Ghosh M, Kim N, Lee SB, Lee HK, Mok YS, Kwon T, Jeong DK. Lethality of inappropriate plasma exposure on chicken embryonic development. Oncotarget. 2017; 8(49):85642-85654.

Zhang Y, Yu C, Wang $\mathbf{L}$. Temperature exposure during pregnancy and birth outcomes: an updated systematic review of epidemiological evidence. Environ Pollut. 2017; 225:700-712. 